\title{
Escaping on the Kindertransport from Democratic Czechoslovakia
}

\begin{abstract}
The documentary film Into the Arms of Strangers (2000) drew the attention of a larger audience to the kindertransport, a unique rescue operation which saved the lives of some 10,000 children, almost all of them Jewish. Most of the children who were sent to the United Kingdom from 1938 until the beginning of the war came from Germany. Although one of the best known kindertransport autobiographies was written by a Czech, Vera Gissing's Pearls of Childhood (1994), not enough attention has been given to the special situation of Jewish children refugees from Czechoslovakia. Until President Benes's exile in the wake of the so-called "Munich Agreement," Czechoslovakia courageously opposed Nazi Germany. Czech refugees who arrived in the United Kingdom could be proud of their country. In contrast, Jewish children refugees from Germany had not only lost their home, but were also suspected of being enemy aliens.
\end{abstract}

\section{Key words}

Kindertransport; Holocaust; Munich Agreement; pre-war Czechoslovakia; exile; Jewish children refugees; Karen Gershon; Vera Gissing; Nicholas Winton; Klaus Mann

The stories of Jewish children who managed to escape the Shoah are no less diverse, startling and terrible than those of adult refugees. For two reasons they might touch us even more than the stories of other survivors. Only some ten percent of Jewish children in Europe actually survived, reminding us that Adolf Eichmann, after the Wannsee Conference, made them a primary target of Nazi prosecution, since he claimed to fear their revenge in post-war Europe. With the exception of a few examples of children who fought their way through to Palestine or other safe havens without parental or adult guidance, most of the 
kinder were too young to have had any rescue option. It was difficult and very often impossible to escape Nazi prosecution, particularly after Germany had started occupying large parts of Europe after the so-called "Munich Agreement" in 1938. Children who were looking for a place of safety were entirely dependent on the support and generosity of adults outside continental Europe, not only for a transitory period before 1938, but throughout the war's turmoil. Much has been said about the kindertransport, ever since this long unrecognized group of refugees surfaced to public knowledge after they started organising gatherings and helping each other to publish their experiences. In this article, I want to focus on the desperate situation Czechoslovakia found herself in during the pre-war period and the impact this had on child refugees to and from Czechoslovakia.

In a preface to Mark Jonathan Harris's and Deborah Oppenheimer's now famous documentary film and book publication entitled Into the Arms of Strangers (2000), film director Richard Attenborough described the idealism of his parents, who decided to take in Jewish refugee children from Nazi Germany. Their mother told his brothers and him that they would accept two girls from Germany. She explained to them that they would do that only on the basis of their consent, because they would become their sisters. Richard and his brothers first did not understand the challenge: "The problem, darlings, is this: your father and I love the three of you so much, but we are going to have to give perhaps even more love to these two girls than we give to you at this time, because, of course, they have none" (Harris and Oppenheimer 2000: $\mathrm{x}$ ). Richard Attenborough admits that this remark had affected his "whole life in terms of my attitude towards those who are not as fortunate as my brothers and I have been" (x).

It was this sense of responsibility which made the kindertransport possible, and it was the same acknowledgment of the dangers these children were exposed to in continental Europe that helped a few similar projects to succeed, in spite of the failure of the participants of the Évian Conference in July 1938 to provide a rescue programme for Jews from Germany. In 1938, Whitehall responded to a resolution by the National Council of Women of Great Britain to make it easier to obtain domestic help, and relaxed some of its regulations, "allowing married couples to obtain domestic permits and lowering the age limit for women from eighteen to sixteen" (Dwork and van Pelt 2009: 151). The applicants had to prove that they could do domestic work. For Anna Roth-Steinova and her husband, just to mention one example, the bureaucratic hurdles were eventually too high to escape Czechoslovakia, after Germany had imposed the so-called "Protectorate of Bohemia and Moravia" in March 1939 (152). It was only Milena, their daughter, who made it to England. She was saved, while her parents could not leave after the outbreak of war in September 1939. Anna wrote to her English friend Dorothy: "I feel awfully sorry that I could not leave in time. It means that I shall live in great sorrows and unquietness, when she [Milena] is there and I am here." Milena never saw her parents again, as we learn from Dwork and van Pelt in Flight from the Reich: Refugee Jews, 1933-1946 (155). 
There were many more efforts to bring children to safety. In the lead-up to the war, a small group of sixty teenagers from Germany and Poland arrived in Australia, travelling on ocean liners with fare-paying passengers. This group was sponsored by Australian Jewish agencies. The "Dunera Boys" escaped to Great Britain on the kindertransport and, at the beginning of the war, became "lowlevel enemy aliens, resident in Britain, who were interned and transported to Australia" on the Dunera, as we learn from Alan Gill's study Interrupted Journeys (2004: xii).

The United States also accepted Jewish refugee children, but did not organize a major kindertransport. Since the 1980s, reunions have been organized by large organizations such as the British Reunion of Kindertransport (R.o.K.) and the North American Kindertransport Association (KTA). At these meetings, "Kinder have been able to meet again after decades, and for many these events have offered for the first time the opportunity to exchange memories with others. Many did not know until then that they were not alone in their fate and that exactly the same happened to others as to themselves" (Göpfert 2004: n.p.). Many books have been published and some film documentaries produced to tell the stories of the kinder. Best known is Into the Arms of Strangers; another is the American documentary My Knees Were Jumping, Remembering the Kindertransports. Emigration, an Austrian documentary, deals with those who went to the United States.

German- and Czech-speaking Jews from Czechoslovakia found themselves in different situations, depending on when they had to escape Nazi persecution. One of the best known stories is that of a 29-year-old London stockbroker. The documentary The Power of Good: Nicholas Winton tells the story of his extraordinary rescue operation that helped many children to escape on eight trains to England and fifteen to Sweden in 1939. When Winton came to Prague shortly after the Munich Agreement, he saw many refugees from the German occupied Czech Sudeten regions. Many of them were in danger of being sent back to Germany by the Czechoslovakian authorities. Winton decided to help, and set up an office at Hotel Europa, situated at Wenceslas Square in Prague. From there, he organized the rescue of 669 children from Czechoslovakia. (More than 15,000 Czech children were killed.) The first train left on the very day before the Germans invaded Prague and the remaining parts of Czechoslovakia, on March 15, 1939. Seven more trains followed, in spite of the occupation. The last train which was meant to leave Prague, on 3 September, 1939, never departed. "None of the 250 children on board was seen again. We had 250 families waiting at Liverpool Street that day in vain. If the train had been a day earlier, it would have come through. Not a single one of those children was heard of again, which is an awful feeling" (Barrow 2002). After the war had begun, this unique operation, which was part of the kindertransport, came to an abrupt end. Today, "Britain's Schindler" is remembered in many places in the Czech Republic, for example on a memorial plaque in Prague's famous Hotel Europa. In 2007, a school in Kunžak was given Nicholas Winton's name. Among Winton's children is Karel Reisz, the director of the films French Lieutenant's Woman and Saturday Night and Sunday Morn- 
ing. Winton was not the only person who helped refugees, and also not the only British citizen to do so. In a broadcast on Czech Radio on May 30, 2009, Michal Frankl of the Jewish Museum in Prague remembered another rescuer of Czech children, Doreen Warriner.

One of the most impressive publications on Winton's rescue operation was written by Muriel Emanuel and Vera Gissing, Nicholas Winton and the Rescued Generation (2002). Vera Gissing is also mentioned in Diane Samuels's dedication to her drama Kindertransport (1998). She published her autobiography, Pearls of Childhood, in 1994. In the book on Nicholas Winton's Rescued Generation, we find a description of how life had become a lottery after the Germans had occupied the remaining parts of Czechoslovakia in March 1939: "Parents who until then could not face the thought of separation, became increasingly desperate to send their children to a safe haven, despite the heartbreak such a separation would bring" (Emanuel and Gissing 2002: 79). Like many other Kinder, Vera Gissing tries hard to imagine what it must have felt like for her parents and other parents to do everything to send their children away: "It is impossible to imagine how the parents must have felt, hoping, yet fearing, that out of thousands of names their child or children would be chosen. What courage and what strength was necessary and a special kind of unselfish love, to make the ultimate sacrifice to part with their children" (80). Many children never saw their parents again, as Gissing noted in an interview for the Telegraph, during which she talked about Winton's rescue operation: "He rescued the greater part of the Jewish children of my generation in Czechoslovakia. Very few of us met our parents again. They perished in concentration camps. Had we not been spirited away, we would have been murdered alongside them" (Barrow 2002). Vera Gissing describes the pains of separation, which traumatized the children. A deep sense of guilt would emerge in them, the guilt of having abandoned their parents.

In England, many siblings had to separate in order to find foster families: "There were complaints that many of the children found their way into Christian homes and institutions, but there was a definitive shortage of Jewish families and hostels in Britain" (Emanuel and Gissing 2002: 81). Gissing reminds us that Czechoslovakian children were among the last to arrive from Europe. Even Winton's transport was not the first. Winton had witnessed a transport selected by the Reverend B. Walner in Prague, on 12 January 1939 (83). Arrivals found many children without much strength to defend their identity: "A large proportion of the children became practicing Christians and have remained so to this day" (85), as Vera Gissing explains - stories that inspired Daniel Samuels to write her drama (1998) about Eva, who became Evelyn and found her way back to her original identity only many years later. Winton's attitude towards this was very pragmatic and gives an idea of how little space must have been left even thinking of restoring individuality and dignity to the fortunate children who could leave: "better a converted Jew than a dead one" (Emanuel and Gissing 2002: 85).

After more than two generations, some people might not be aware of the fact that the continuous escape from the advancing German troops actually began 
as early as the Munich Agreement. In autumn 1938, many Czechoslovakians, including Jews, started to escape the Nazis, first to the remaining Czechoslovakia of the Second Republic (1938-39), and then to other mainly European countries which would soon also be occupied after Poland was invaded on September 1, 1939.

Deprived of their rights as citizens in all German-controlled countries, Jews became migrants without a passport, as W. H. Auden explains in his famous poem "Refugee Blues." In a similar poem, Gerda Mayer talks about how desperate the situation was for Jews trying to reach another country. In both poems, March 1939 is seen as a decisive turning point. Auden describes how Jewish refugees lost their country: "Once we had a country and we thought it fair, / Look in the atlas and you'll find it there: / We cannot go there now, my dear, we cannot go there now" (Auden 11. 4-6). After March 1939, only a very few people could doubt that war in Europe was inevitable: "Thought I heard the thunder rumbling in the sky; / It was Hitler over Europe, saying, 'They must die': / O we were in his mind, my dear, O we were in his mind" (11. 19-21). It was "the second violation of Czechoslovakia within one year," as Thomas Mann's son Klaus writes in his autobiography The Turning Point, which was published while he was in exile in America in 1944. The invasion of Prague in March 1939 made it "evident that public opinion in Britain awakened to the enormity of the Nazi challenge" (Mann 1944: 251). For Jewish exiles such as Gerda Mayer, surviving became more and more difficult in this situation (Emanuel and Gissing 2002: 125-26). She found herself playing "The Emigration Game" with her mother while they "walk through the streets of Prague" (1.1): "We have a bag of chocolate-creams; we play / The Emigration Game: England, if brown; / Or, if the centre's white, we must stay here; / If yellow, it's Australia. Snow falls down" (Mayer 11. 5-8). All hopes for emigration were destroyed in March 1939, when "the fiasco of Chamberlain's scheme" (Mann 1944: 251) had become obvious: "Then March comes and invaders bar all routes: / Yet leave no trace of her when they move on" (Mayer 11. 15-16).

Klaus Mann pointed out the significance of pre-war Czechoslovakia for democracy and peace, when he described how "Hitler's brassy determination to violate and rob Czechoslovakia no matter what the consequences might be" (1944: 248) was discussed in New York during a "monster meeting on behalf of Czechoslovakia" (248). Klaus Mann describes "the disgrace of Munich," which followed the "collapse of the Spanish Republic" (249), in the following words, words that explain why the policy that made the so-called "Munich Agreement" possible was "dictated by human cowardice, short-sightedness and ignorance" (249):

The conspiracy of Munich was the most devastating blow to the cause of peace and democracy. [...] The cynical betrayal of Czechoslovakia, the last outpost of democracy in Central and Eastern Europe, could not but weaken and hurt our side, irreparably perhaps. Chamberlain's "Peace with Honour" was a dishonourable defeat. (248) 
The tragedy of the two violations of Czechoslovakia is reflected, in many ways, in the autobiographical writings of exiles in Great Britain. One way for them to approach their feelings of helplessness was to write about the loss of language. Children in exile who lost their language were also in danger of being deprived of their identity. Jewish people in pre-war Czechoslovakia would have spoken either German or Czech as their mother tongue, depending on whether or not they belonged to the German-speaking minority in Czechoslovakia. Therefore, Vera Gissing attached to her widely read autobiography Pearls of Childhood a "Note on Accents," in order to help readers to pronounce Czech words properly. In her new English-speaking environment, Vera feared that she would lose her "beloved Czech language" (Gissing 1994: 37). In one of the first conversations she had with a girl from Czechoslovakia, she was warned that languages not practiced are quickly lost. Although Maria's Czech was learnt at school, Vera fears the same for her Czech:

I couldn't help noticing how badly Maria spoke, and I asked with the directness of a child, "Why is your Czech so bad?" "When you've been here a year like I have," she replied, "without ever having a chance to speak it, you'll probably forget it altogether." I was horrified at the very thought. To return to my parents able only to speak in broken Czech, or not to speak Czech at all ... that was unthinkable! I vowed never to let that happen to me. I would not forget my language, not a single word! In fact, Maria was a refugee from Sudetenland that had a German education and had never learned the Czech language properly. Nevertheless she did me a good turn, for I took her warning to heart and became doubly determined not to forget my mother tongue. (38-39)

Vera also spoke German fluently, but she "had vowed never to speak German again" (44). She did that, although her teacher spoke German and could have helped her. In this way she learnt English even faster, she says. In order not to lose her Czech, however, Vera explains how she kept re-reading her few Czech books over and again: "As I rarely had other Czechs to talk to, I often held long conversations with my doll" (48). This all too patient listener was soon replaced by Jill, the family's dog, whom she teaches Czech after school. Vera was "thrilled when she learned to respond to a few basic commands. I liked to sneak her up to my room, which was strictly forbidden, and to cuddle her and to tell her in Czech about my home, my horse and my cats" (55).

This strong interest in keeping her Czech language alive is accompanied by anything connected with Czechoslovakia: "Whenever Czechoslovak music was played, I almost wept with joy. Whenever Czechoslovak forces were mentioned, my heart swelled with pride. These men were my personal heroes, for they were fighting for the freedom of my country and for my return home" (Gissing 1994: 68). Vera's "longing for all that was Czech" (68) makes the Rainfords, her foster parents, look for opportunities for Vera to meet fellow countrymen in exile. Vera shows a thorough knowledge of Czech politics and the various involvements of 
the Czechs in the war against Nazi Germany. At the centre of this longing for all that is Czech remains the language itself: "Oh, how wonderful it was to hear the sound of a Czech song in a foreign land," Vera writes about the gatherings of Czech exiles in the UK which she attended (69).

In literature on the kindertransport, Vera Gissing's recurring statements about the supporting role her Czech native tongue played for her are as rare as they are significant. German-speaking Jewish children from Germany, Austria, and Czechoslovakia did not have this choice and privilege. They would not be in a position to wish for the liberation of their respective countries either. On the contrary, they wanted to get rid of the language of the people who had betrayed, persecuted and humiliated them. After the onset of the war, their German would even give them away as alleged enemy aliens. Even before their emigration, they would have gone through a years-long period of humiliations that would sometimes have triggered feelings of self-doubt or even self-hatred, as Karen Gershon describes in her autobiography about the years prior to her escape on a kindertransport from Bielefeld to England.

Being a Czech kindertransport refugee, Vera Gissing would not be mistaken for an enemy alien, but rather as someone seeking the opportunity to give comfort to the wounded Czech soldiers who had escaped German-occupied Europe. "Sometimes I was asked to write a letter in Czech, or even to compose one in English. That made me feel very grown up" (1994: 73). Through identifying with one language and one country, Vera could participate in the war effort and watch herself growing up. For most German-speaking Jewish refugees of the kindertransport, things were different. They would have been ostracized before and after their escape. For the Nazis and their supporters, they were Jews; for many of the English and their authorities, they were Germans. Vera knits socks for allied soldiers and is convinced, she says: "I knit twice as fast as everyone else, but of course the Czech way is much better and faster than the English way" (74). Vera visits a Czech military camp in North Wales and finds herself in contact with many exiles from Czechoslovakia who had escaped in the wake of the fall of France. The Czech exiles bring their language to England and publish a newspaper for the Czech community, The Czechoslovak (76).

The war situation made it possible for young Vera to have feelings of national belonging, in exile. Obviously, this helped her a lot when she found herself all on her own in a foreign country. "My parents were not forgotten; they were with me constantly" (77), writes Vera Gissing. The danger of alienation and of the loss of her Czech identity are even less imminent after she learns from President Benes himself that she could attend a school for Czech exiles in England (84). Benes explains to her: "The teachers are mostly Czech too. I am sure you will like it there, for the school is like a tiny Czechoslovak colony and such a friendly place" (84). The education in that Czechoslovak State School in Britain was bilingual and helped to keep the children in touch with "Czech culture and traditions," as Vera Gissing points out (85). The pupils had very different backgrounds, with respect to both class and ethnicity. Some children had been too young when they 
came to England to keep their Czech mother tongue; others, such as Jews or political refugees "who had fled from the German-speaking Sudetenland had never learned Czech properly." A few children had moved to the UK with their parents, who worked for various companies, well before the war (86). Vera Gissing mentions repeatedly that immigration to the UK for Germans was quite difficult, for obvious reasons, in spite of the fact that all of them were fleeing from the Nazis, either for political reasons or because they were Jewish.

Although Vera Gissing is very patriotic throughout her biography, she has a keen sense for people who do not belong to either side and, therefore, encounter hardships and injustices. The boy she fell in love with at the age of fifteen was the son of political refugees. Walter from Sudetenland could not stay at Hinton Hall because his Czech was too poor (Gissing 1994: 107). Because of his German origins, he was "consumed with shame and guilt," as Vera learned later (107). Peter was the son of a German mother and a Czech soldier who had become separated from his family. Both were detained, on arrival, in Holloway Prison, and Peter was transferred to a German children's home in Wandsworth: "He was very Czech and he hated it there" (88). Only after he wrote a letter to Benes was he transferred to Hinton Hall, upon the president's intervention.

Vera observed nationalist feelings even in some teachers from the British Council who, in supporting the Czech school, "even developed into real Czech chauvinists," as Vera explains (Gissing 1994: 91). Czech nationalism reflected on the helplessness of citizens at a time when German occupation had deprived the whole country of its freedom and had forced many others into exile. Fascism and Nazism had destroyed the very belief in the strength of democracy and freedom, even before the war, as another German exile, Walter, explains in his autobiography.

Klaus Mann, who admired Benes' courage in opposing the Nazi threat, wrote about the relationship between the fall of the Spanish Republic and the invasion of Czechoslovakia: "Like Benes of Czechoslovakia, Alvarez del Vajo believed that a good cause and sound intelligence have more of a fighting chance than an evil cause and morbid stupidity, even if the evil and stupid side happens to be more formidably equipped, for the time being" (1944: 243-44).

In spite of the fact that Czechoslovakia rejected many German exiles, many others, both gentiles and Jews, cherished Czechoslovakian hospitality during a period when the situation became more and more dangerous from the so-called "Munich Agreement" to March 1939. Klaus Mann and almost his entire family, for instance, received Czechoslovakian citizenship from President Benes, who resigned on 5 October 1938 and went into exile to London.

Klaus Mann had visited Prague in 1937. In spite of the threat of Nazism, Prague (in contrast to Vienna) "appeared self-assured and productive" (1944: 236). Klaus Mann describes the Czechs as "a fine people [...] imaginative, brave, and liberal," and explains that he makes

[...] this statement unafraid of being called a Czech nationalist, although it happens that I am not only an admirer of Czechoslovakia but also a citizen 
of that country. Thanks to the generous gesture on President Benes's part, my whole family - excepting Erika, who is a British subject - was granted the citizenship of Czechoslovakia. I was entitled, therefore, to feel at home for a change while sojourning on Czechoslovakian ground. (236)

The pride Klaus Mann takes in being a Czechoslovakian citizen is that of a European democrat for whom fighting for a just cause is more important than an identity acquired by birth. In order to understand why Czech nationalism in Vera Gissing's autobiography and in the writings of other emigrants is such an essential experience during that period, it might be helpful to continue reading Klaus Mann, for whom this nationalism was a commitment to that democracy which had its roots in the history of this country:

Far from being worn-out and depleted, the Czechs emerge from all their tribulations with unabated hopes and energies. It may be that the true source of this resilient vitality is an inborn faith and a natural disposition through which the Czechs differ, again, from all other European peoples east of France. The Czech people are democrats by nature and tradition. (236)

Klaus Mann's words reflect very well the hopes many exiles associated with Czechoslovakia in the pre-war period. Klaus Mann voices what we also read in Vera Gissing's autobiography, a strong belief that the Czech cause would eventually prevail. In The Turning Point, Klaus Mann quotes President Benes who told him in an interview in 1937: "Don't be afraid. [...] Bad things may happen - in Spain, here, everywhere. The evil may become mighty strong: but the good is stronger. Wait and see, my good friend! Our side is much stronger!" (1944: 237). In 1937, this belief in freedom and democracy required a lot of courage and vision. While in exile in America in 1944, when he quoted from this interview, which he described as one of his "most cherished memories" (237), Klaus Mann would not have had the certainty that President Benes was right.

Another famous German writer who escaped to Czechoslovakia is Stefan Heym. At the end of the war, he returned to his home country as a U.S. soldier. Until his escape from Chemnitz to Czechoslovakia, his name was Helmut Flieg. He boarded the local train for Silesia, walked to the Spindlerbaude, entered its "warm, crowded Stube (bar) [...] walked right through to the toilets, thus crossing from German into Czech territory. [...] On the Czech side he was recognized as a refugee by a bus driver who offered him a ride to the city. There he took the alias Stefan Heym, which he kept for the rest of his life" (Dwork and van Pelt 2009: 12-13). Soon even the toilets of the Spindlerbaude would be German-occupied. In the preface to their book Escape to Life, Klaus and Erica Mann describe this development in the following words: "The number of those who no longer can or want to remain in the Reich has become steadily larger. Consider also that the sphere of influence of the Hitler dictatorship is reaching ever greater proportions. Day before yesterday new emigrants arrived from Austria; yesterday they came 
from Czechoslovakia; today the victims of the latest Nazi pogroms reach here from German cities" (1939: vii). The number of victims of what Karel Capek, in one of his most successful pre-war plays about fascism, called "The White Sickness" was growing, Capek being one of them (see Klaus Mann 1939: 156-57).

Like Stefan Heym, Vera Gissing was a Jewish refugee. After what has been said about Czechoslovakian democracy, it is troubling to read that Vera Gissing was barred from returning home by experiences of anti-Semitism, and that Vera's feelings of patriotism for her home country were eventually disappointed. She learns that her father had been betrayed by a collaborator in her home town, Celakovice (Gissing 1994: 97). Recurring experiences of anti-Semitism lead to the decision to turn her back on Czechoslovakia in 1947. Her boy-friend is chided as a "Jew-lover" (166). Her Czech pride and anti-Semitism collide in the most dreadful way when the captain of a paddle-streamer tells them: "Those lousy Germans [...] The only favour they did to us was to kill so many Jews. It's a shame they didn't do the job properly and finish off all of those bastards" (166). Vera comes to the conclusion that anti-Semitism might be somehow bearable anywhere else in the world but not "in my own - still beloved - country" (166) and decides to leave. In the wake of the liberation in 1945, this had still sounded quite different: "There was a lump in my throat, and I silently vowed, 'I am Czech, I shall always be a Czech"' (118). After the war, the question arose whether one should return home as soon as possible, or instead stay in England. While the head of Hinton Hall strongly advised Vera to return to Czechoslovakia, Auntie Berta sent "a telegram advising Eva and me to remain in England" (133). Vera ignores this: "At this crucial point in my life I could not envisage a future anywhere but in Czechoslovakia. My patriotism, nurtured by the school, burned fiercely [...]" (134).

What we read about pre-war Czechoslovakia in the autobiographies of Klaus Mann and Vera Gissing, a German writer and a Czech Jewess, converges in a resilient belief in the national pursuit of Czech freedom and democracy, as part of a larger European project which seemed to be entirely shattered during the years of the war. Vera Gissing's autobiography shares much more with Klaus Mann's political analysis than it does with autobiographies of other Jewish refugees of the kindertransport written by Jewish children coming from Germany. They did not have either the independent authority of a writer such as Klaus Mann or the assuring protection even an occupied home country like Czechoslovakia could give to a young Czech refugee in exile in England.

In contrast, Jewish refugees of the kindertransport from Germany had lost everything. Having grown up in a dying democracy or Nazism, they could not imagine a world different from the one which had turned them into unwanted and persecuted people. They had neither a country nor a political vision. For Jewish children from Germany, writing their autobiographies and finding a voice of their own was more difficult, as one can see in Karen Gershon's autobiography, which was published very late in her life. Before she even started writing a personal autobiography, Karen Gershon published a "collective autobiography" of 
the kindertransport, We Came as Children. Her personal autobiography, A Lesser Child, published in German translation under the title Das Unterkind in 1992, was followed by a second part, A Tempered Wind, which was published in 2010 and covers the time from December 1938 until the end of the war (for a more detailed analysis of Gershon's autobiographical works, see Houswitschka 2004: 73-85).

The narrative sets in shortly before Hitler comes to power, and tells of the Jewish life in Germany that was destroyed, more and more, by Nazi persecution. Käthe is a girl who tries to compete with her sisters. Her futile attempts to catch up with them made her, as she says, "a lesser child even before the Nazis came to power" (Gershon 1994: 13). Her relationship with her mother and her sisters is one of the main topics, the process of becoming a poet and writer is another. Becoming a poet and writer is impossible without constructing her Jewish identity. This was particularly difficult for Käthe Löwenthal because she lacked both political awareness and personal self-esteem: "[Käthe] would always be too unsure of her identity to be willing to pretend she was someone else" (69). Käthe's personal problems with herself are made even worse when the pressure on German Jews increased. While Brunhilde tells her, "What's wrong with being known to be a Jew? It's something to be proud of" (68), Käthe cannot see the political relevance of such a statement. Käthe would have preferred "not to have been a Jew at all but an Aryan" (69). However, Käthe's shyness is not only an individual problem, but also a collective one. This child could not cope with the experiences of the growing pressure and collective contempt from an increasing number of Germans, who were Nazis or supported them when they withdrew from their Jewish neighbours. When her father encounters financial problems due to Nazi laws, he refuses to answer the telephone and makes his daughters tell his business partner that he is not at home. The narrator comments on this in a manner that does not pass judgment on her father but pities his situation: "That was the sort of thing the Nazis did to the Jews which is not mentioned in the history books: they made upright men tell their children to tell lies" (113).

Gershon shows how Jews were bereft of their self-esteem through Nazi propaganda (1994: 115). The propaganda was effective enough to raise doubts even among the Jews. Käthe could not help believing "that there was at least some truth in what the Nazis were saying about the Jews" (115). "There must be something the matter with the Jews," (115) she surmises. Anne was the only one to see clearly what was going on: "I would be against the Nazis even if they suddenly started loving the Jews," she says (116). Gershon admits that she agreed only after she had grown old enough to understand. "But not wanting to be a Nazi was different from wanting to be a Jew" (116).

Being a German Jew, first in Nazi Germany and then in war-stricken England, made her feel unaccepted by other people, as she describes in A Tempered Wind: "Like a child who believes himself to be invisible with closed eyes, I still believed that because I wanted to belong, because I felt the need to belong, I would be able to do so" (Gershon 1994: 133). 
In A Tempered Wind, Käthe emphasizes that what self-esteem survived the Nazi environment consisted in her ability to write. How different her experiences were as a German Jews compared to those of Czech Vera Gissing, which one can see from the problems she had in choosing the right language for her writings. From the very beginning, the problem of language reflects the situation in which she finds herself. First she believed that she would be writing in Hebrew. This was supported by her ambitions to join the Zionists, who organized daily Hebrew classes, which helped Käthe to start writing "stories, and essays, and poems, and a whole sequence of 'Letters from Jerusalem"” (Gershon 2009: 50). The longer she was in England, however, the more she tried to write in English. Writing became so important to her that she "almost stopped feeling homesick and began to feel almost happy" (50). Although she was ridiculed for her writing, which included poems "predicting the catastrophe which was to befall the Jews of Germany" (65), the opposition among her peers could not stop Käthe: "I thought that if going to the Land of Israel would stop me from being a writer, then I would not go there" (67).

In spring 1941, Käthe decided to become an English writer and burned all the German poetry and prose she had, even a letter she had received from Stefan Zweig (Gershon 2009: 92). After moving to Leeds, she looked for opportunities to be among English people and to read in order to improve her English: "Dylan Thomas made me fall in love with the English language," she writes (103). Writing in the new language was a difficult task: "I needed to write as I needed to breathe, and continuing to write also in German was my escape route: the one way still available to me of returning home" (103). On the other hand, writing in German made her see herself "as a Jew who happened to have been born in Germany" (116) - an experience which made it impossible for her to value the poems she wrote in German any longer, although she realized that her English poems were no more than exercises. Writing created a place of belonging and understanding which made it possible for her to remain autonomous and to control the experiences of her childhood. Recalling conversations which took place when she was 16 years old, she wonders whether she might be considered English at the age of thirty-one and is told: "You will never be other than a Jew [...] who happens to have been born in one country and happens to live in another. You won't belong" (54). Käthe's problems were those of many Jewish children from Germany who had escaped Nazi persecution. The "Refugee Children's Movement" wrote about this problem: "we encouraged them to drop their German language. $[\ldots]$ we are now faced with a problem where we have a child who has forgotten all its German, and its parents, with whom we hope one day it will be reunited, speak no English" (Göpfert 2003, 117-18).

In this article different types of emigrant autobiographies have been compared. The focus has been on the differences between two kindertransport survivors, Vera Gissing and Karen Gershon, alias Käthe Löwenthal. While Vera found a new home in England among her Czech compatriots and found her Jewishness collide with her Czech citizenship only after the war, Käthe had vast problems retaining 
her Jewish identity because of her childhood in Nazi Germany. Czechoslovakia was regarded by many as a beacon of freedom and democracy in pre-war Europe. This boosted the self-esteem of young Vera, who had the opportunity to meet President Benes while in exile in England, just as famous Klaus Mann did before the war. In contrast, Käthe had to face hostilities from some English people who mistook her as an enemy alien and did not accept her as another victim of Nazi persecution. On the other hand, she was tempted to dislike herself for being Jewish as long as she could not get rid of her German identity altogether.

Children who escaped from Czechoslovakia had to cope with the same hardships other refugees had to face. However, children whose mother tongue was German, saw themselves caught up in a situation where they did not only lose their homes and very often their families, but also wanted to get rid of the language which had turned against them.

\section{References}

Auden, W. H. (1995) 'Refugee Blues'. Repr. in: Schiff, Hilda (ed.) Holocaust Poetry. New York: St. Martin's Griffin Press. 12-13.

Barrow, Becky (2011) 'The British Schindler wins knighthood at 93'. The Telegraph. 31 December 2002. <http://www.telegraph.co.uk>.

Dwork, Debórah, and Robert Jan Van Pelt (2009) Flight from the Reich: Refugee Jews, 1933-1946. New York and London: W. W. Norton.

Emanuel, Muriel and Vera Gissing (2002) Nicholas Winton and the Rescued Generation. Foreword by Ester Rantzen. $3^{\text {rd }}$ ed. London: Vallentine Michell.

Gershon, Karen (ed.) (1966) We Came as Children. London: Gollancz.

Gershon, Karen (1992) Das Unterkind: eine Autobiographie. Reinbek: Rowohlt.

Gershon, Karen (1994) A Lesser Child. London: Peter Owen.

Gershon, Karen (2009) A Tempered Wind: An Autobiography. Ed. with intro. by Phyllis Lassner and Peter Lawson. Evanston, Illinois: Northwestern University.

Gill, Alan (2004) Interrupted Journeys: Young Refugees from Hitler's Germany. Pymble: Simon and Schuster.

Gissing, Vera (1994) Pearls of Childhood. London: Robson Books.

Göpfert, Rebekka (2003) 'Kindertransport. Geschichte und Erinnerung'. In: Benz, Wolfgang, Claudia Curio, and Andrea Hammel (eds.) Die Kindertransporte 1938/39. Rettung und Integration. Frankfurt: Fischer. 34-44.

Göpfert, Rebekka (2004) 'Kindertransport: History and Memory. In memoriam Erna Nelki'. Shofar. N.p. 22 September 2004. <questia.com>.

Harris, Mark Jonathan, and Deborah Oppenheimer (2000) Into the Arms of Strangers: Stories of the Kindertransport. London: Bloomsbury.

Houswitschka, Christoph (2004) "“What I was going to be I already was: a writer" - Karen Gershon and the Collective Memory of the Kindertransport'. In: Behlau, Ulrike and Bernhard Reitz (eds.) Jewish Women's Writing of the 1990s and Beyond in Great Britain and the United States. Trier: WVT. 73-85.

Janzer, Till (2009) '100. Geburtstag von Nicholas Winton - Gedenken an eine beispiellose Rettungsaktion'. <http://www.radio.cz/de/rubrik/geschichte/100-geburtstag-von-nicholas-wintongedenken-an-eine-beispiellose-rettungsaktion.30-05-2009>.

Mann, Klaus, and Erica Klaus (1939) Escape to Life. Boston: Houghton Mifflin. 
Mann, Klaus (1944) The Turning Point: Thirty-Five Years in the Century. London: Victor Gollancz. Mayer, Gerda (2002) 'The Emigration Game'. In: Emanuel, Muriel and Vera Gissing (eds.) Nicholas Winton and the Rescued Generation: The Story of 'Britain's Schindler'. $3^{\text {rd }}$ rev. London: Vallentine Mitchell. 125-126.

Christoph Houswitschka has, since 2002, held the Chair of English Literature at the University of Bamberg. Prof. Houswitschka has taught at the Universities of Regensburg, Dresden, Northern Iowa, and Freiburg. Since 2005 he has been a visiting professor at the Jiaotong University, Xi'An. His research areas include Arthurian literature; law, politics and literature in the eighteenth century; contemporary drama; and literature in English dealing with National Socialism and the Shoah. He has edited Freedom - Treason - Revolution: Uncollected Sources of the Political and Legal Culture of the London Treason Trials (1794) (2004) and co-edited Einführung in das Studium der Anglistik und Amerikanistik [Introduction into English and American Studies] ( $2^{\text {nd }}$ edition, 2007) and several conference volumes, e.g. Staging Displacement, Exile and Diaspora (2005), Literary Views on Post-Wall Europe (2005), and Healers and Redeemers (2010).

Address: Prof. Christoph Houswitschka, Institut für Anglistik \& Amerikanistik, Otto-FriedrichUniversität Bamberg, An der Universität 9, D-96045 Bamberg, Germany. [email: christoph.houswitschka@uni-bamberg.de] 